Supporting Information

\title{
Synthetic Mimics of Native Siderophores Disrupt Iron Trafficking in Acinetobacter baumannii
}

\author{
Tabbetha J. Bohac ${ }^{1}$, Luting Fang ${ }^{1}$, Victoria S. Banas ${ }^{1}$, Daryl E. Giblin, \\ and Timothy A. Wencewicz* \\ Department of Chemistry, Washington University in St. Louis, One Brookings Drive, St. Louis, \\ MO, 63130, USA
}

\section{$\underline{\text { Table of Contents }}$}

I. Supporting Figures S2-S7

II. Compound Characterization Data S8-S25

III. Acknowledgements S26

IV. References S26

${ }^{1}$ These authors contributed equally to this work.

*Correspondence to TAW: Email: wencewicz@wustl.edu; Ph: 314-935-7247; Fax: 314-9354481; ORCID: 0000-0002-5839-6672 


\section{Supporting Figures}

Fluorescence Quenching of BauB by Siderophore 1

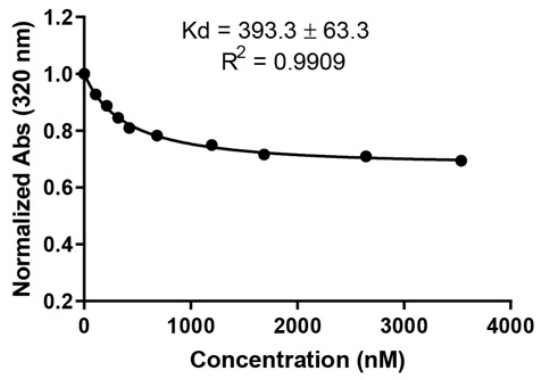

Fluorescence Quenching of BauB by Siderophore 2

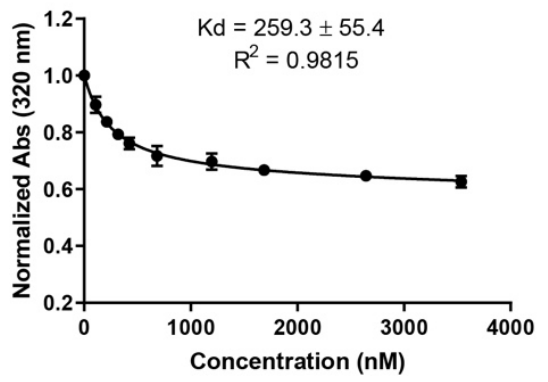

Fluorescence Quenching of BauB by Siderophore 3

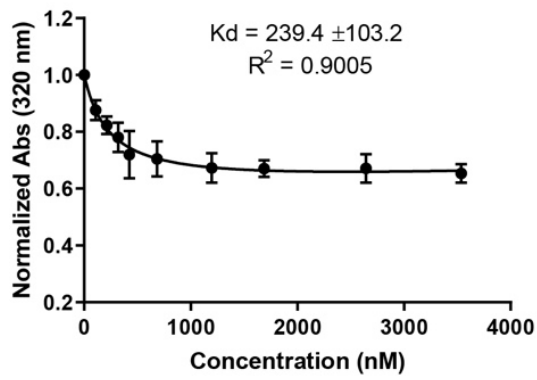

Fluorescence Quenching of BauB by Siderophore 1 - Fe

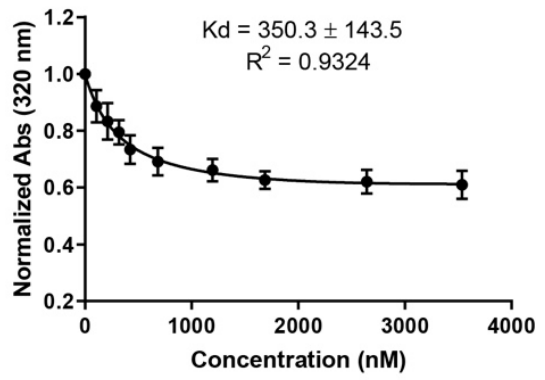

Fluorescence Quenching of BauB by Siderophore 2 - Fe

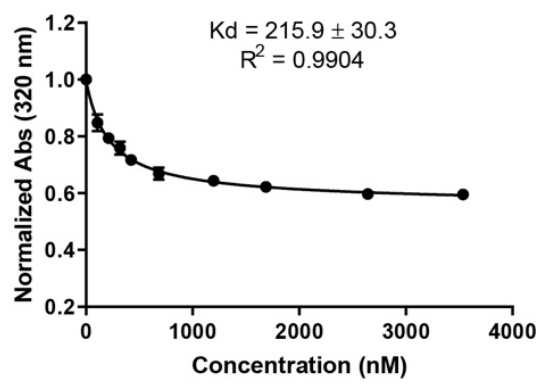

Fluorescence Quenching of BauB by Siderophore 3 - Fe

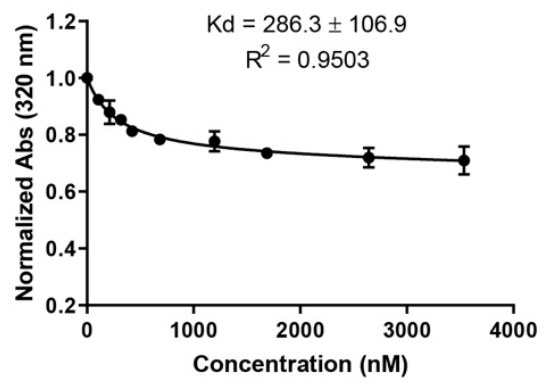

Figure S1. Fluorescence Quenching of BauB by fimsbactin analogs 1-3 and their respective ferric iron complexes 1-Fe, 2-Fe, and 3-Fe. Graphs depict intrinsic fluorescence quenching $\left(\mathrm{y}\right.$-axis; $\left.\lambda_{\text {excitation }}=280 \mathrm{~nm} ; \lambda_{\text {emission }}=320 \mathrm{~nm}\right)$ of $N$-His 6 -tagged recombinant BauB at $400 \mathrm{nM}$ treated with varying concentrations of test compounds (x-axis). Apparent $K_{\mathrm{d}}$ values were calculated using a single-binding mode model using GraphPad Prism v7.0b. Error bars represent standard deviations for three independent trials. 

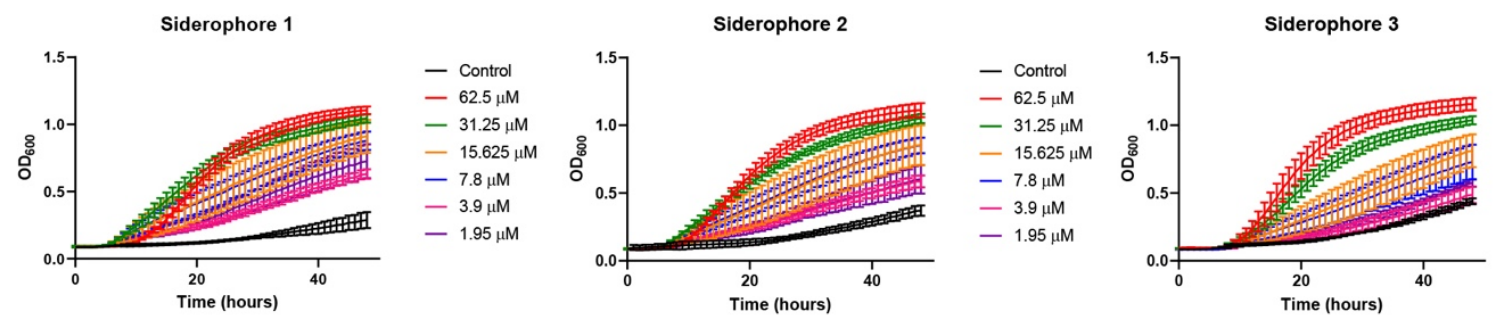

$$
\begin{aligned}
& - \text { Control } \\
& -62.5 \mu \mathrm{M} \\
& -31.25 \mu \mathrm{M} \\
& -15.625 \mu \mathrm{M} \\
& -7.8 \mu \mathrm{M} \\
& -3.9 \mu \mathrm{M} \\
& -1.95 \mu \mathrm{M}
\end{aligned}
$$
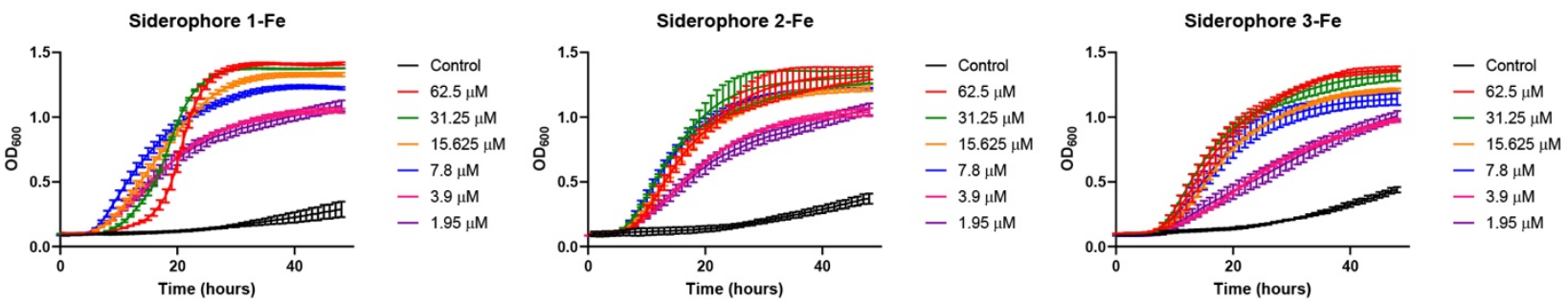

Figure S2. Growth of A. baumannii ATCC 17978 in iron deficient M9-succinate minimal media supplemented with variable concentrations of fimsbactin analogs 1-3 or their respective ferric iron complexes 1-Fe, 2-Fe, and 3-Fe. Bacterial growth is represented on the $\mathrm{y}$-axis as the optical density at $600 \mathrm{~nm}\left(\mathrm{OD}_{600}\right)$ as a function of time in hours (x-axis). Error bars represent standard deviations for three independent trials. 

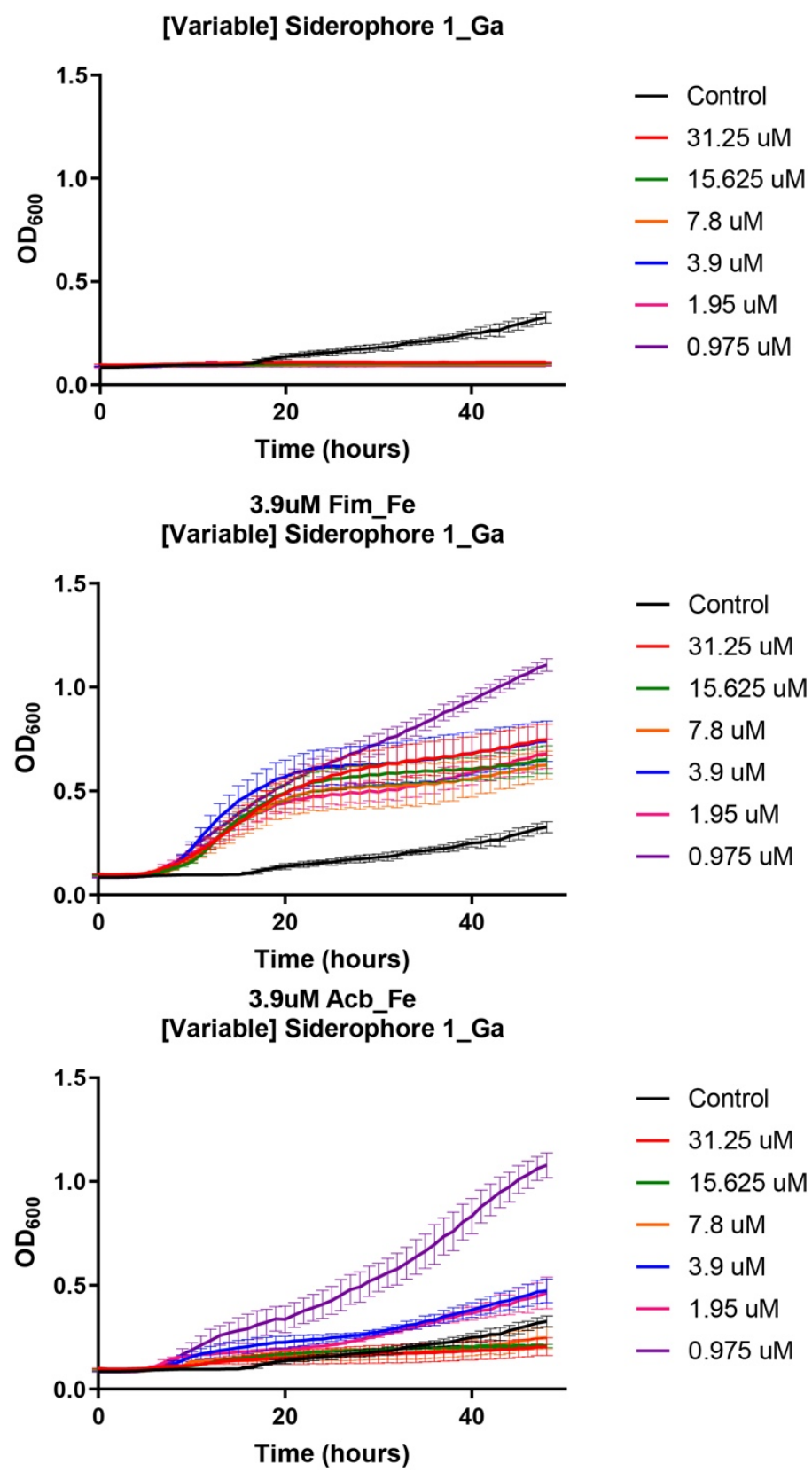

Figure S3. Growth of A. baumannii ATCC 17978 in iron deficient M9-succinate minimal media supplemented with variable concentrations of the fimsbactin analog $1 \mathrm{Ga}$ (III) complex, 1-Ga, supplemented with buffer control (top), $3.9 \mu \mathrm{M}$ Fim-Fe (middle), or $3.9 \mu \mathrm{M}$ Acb-Fe (bottom). Bacterial growth is represented on the y-axis as the optical density at 600 $\mathrm{nm}\left(\mathrm{OD}_{600}\right)$ as a function of time in hours (x-axis). Error bars represent standard deviations for three independent trials. 


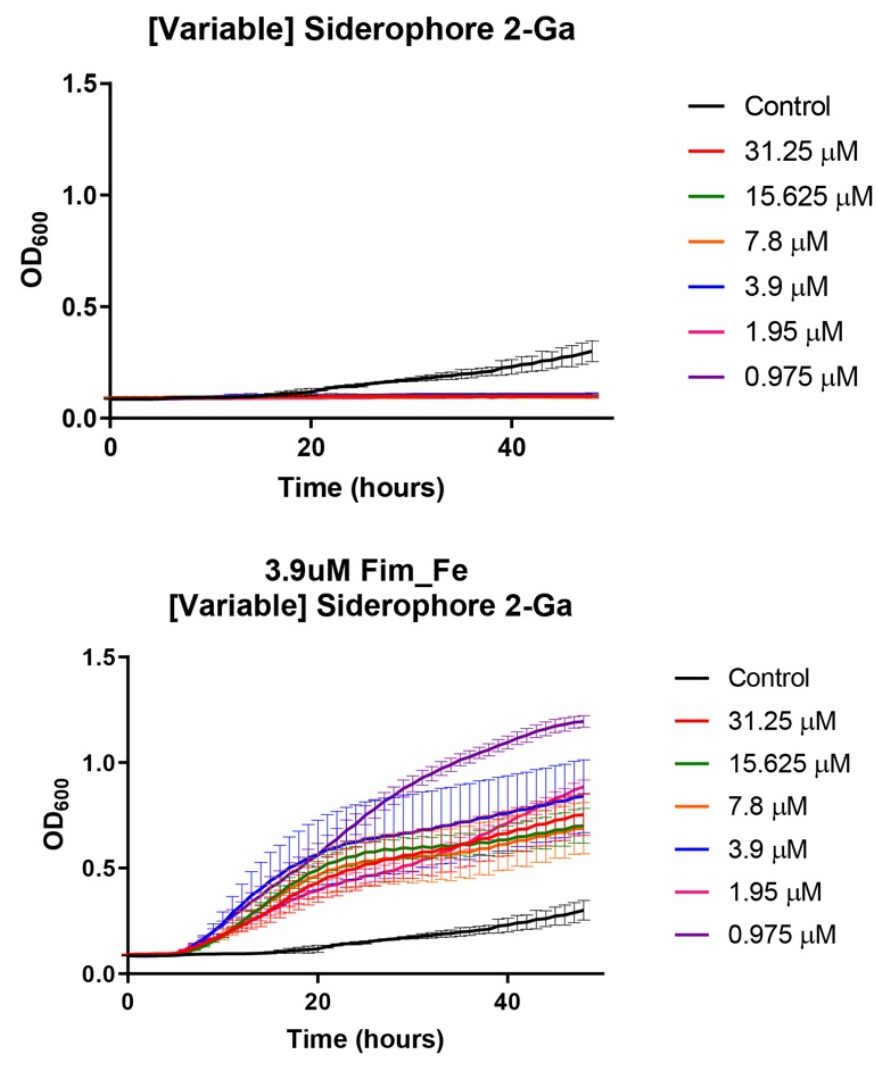

3.9uM Acb_Fe

[Variable] Siderophore 2-Ga

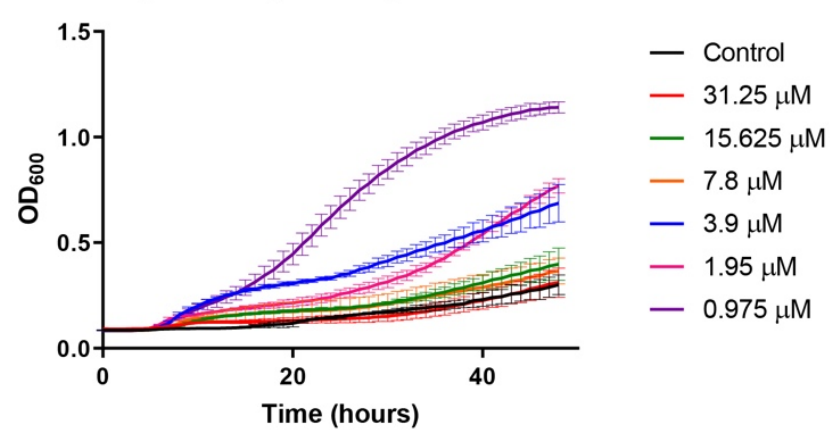

Figure S4. Growth of A. baumannii ATCC 17978 in iron deficient M9-succinate minimal media supplemented with variable concentrations of the fimsbactin analog 2 Ga(III) complex, 2-Ga, supplemented with buffer control (top), $3.9 \mu \mathrm{M}$ Fim-Fe (middle), or $3.9 \mu \mathrm{M}$ Acb-Fe (bottom). Bacterial growth is represented on the y-axis as the optical density at 600 $\mathrm{nm}\left(\mathrm{OD}_{600}\right)$ as a function of time in hours (x-axis). Error bars represent standard deviations for three independent trials. 


\section{[Variable] Siderophore 3-Ga}

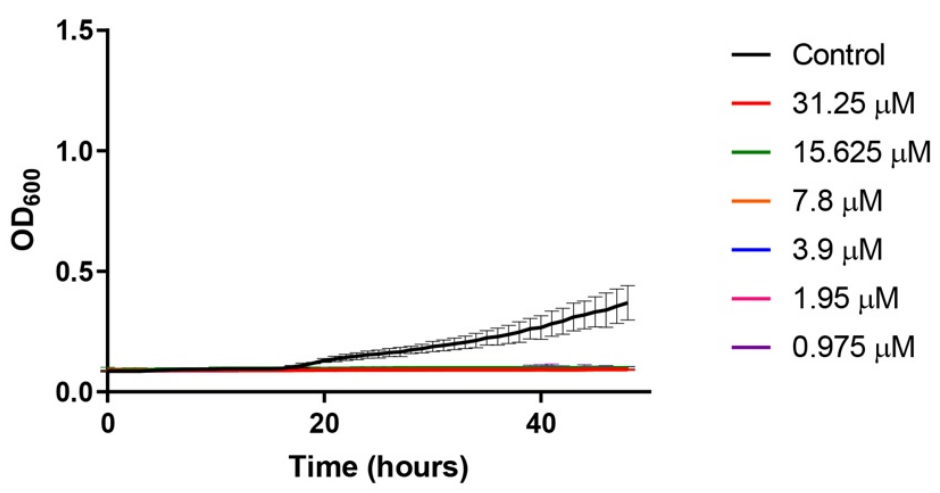

3.9uM Fim_Fe

[Variable] Siderophore 3-Ga

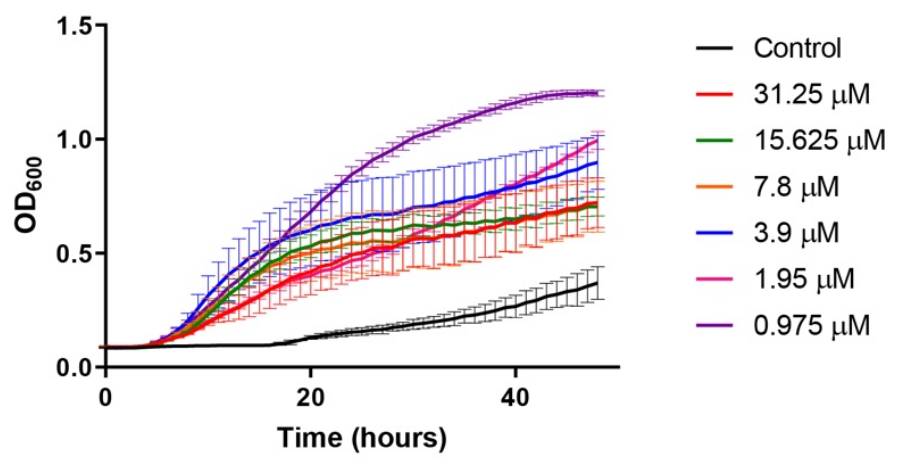

3.9uM Acb_Fe

[Variable] Siderophore 3-Ga

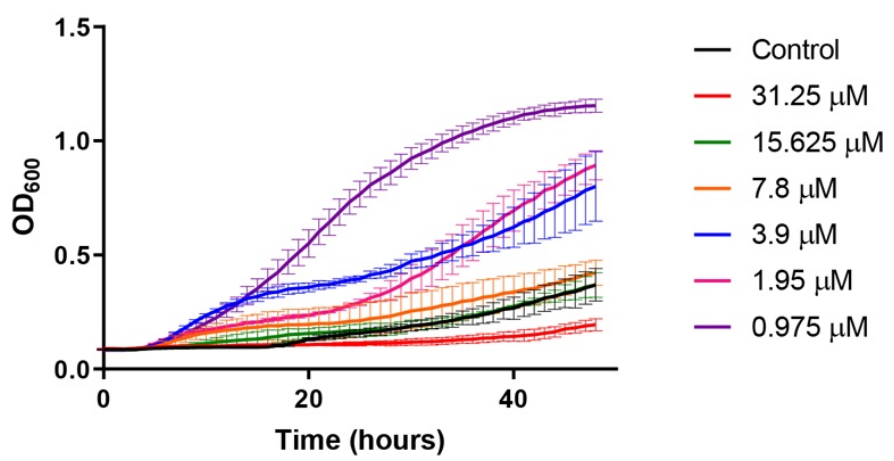

Figure S5. Growth of $A$. baumannii ATCC 17978 in iron deficient M9-succinate minimal media supplemented with variable concentrations of the fimsbactin analog $3 \mathrm{Ga}$ (III) complex, 3-Ga, supplemented with buffer control (top), $3.9 \mu \mathrm{M}$ Fim-Fe (middle), or $3.9 \mu \mathrm{M}$ Acb-Fe (bottom). Bacterial growth is represented on the y-axis as the optical density at 600 $\mathrm{nm}\left(\mathrm{OD}_{600}\right)$ as a function of time in hours (x-axis). Error bars represent standard deviations for three independent trials. 


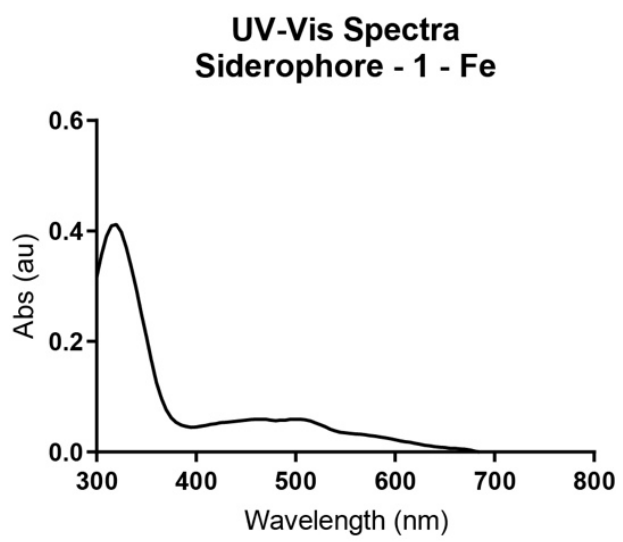

UV-Vis Spectra

Siderophore - 2 - Fe

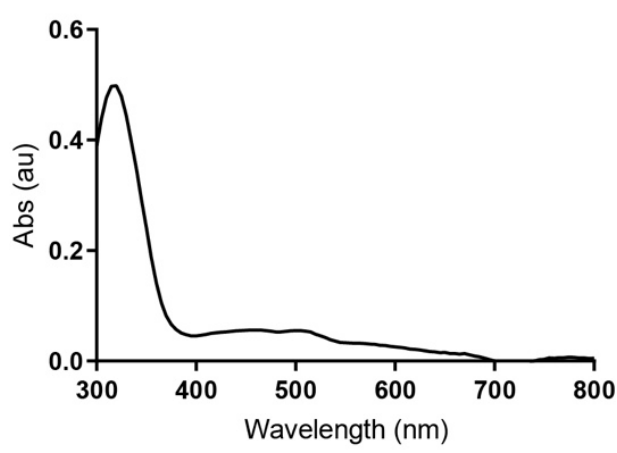

UV-Vis Spectra

Siderophore - 3 - Fe

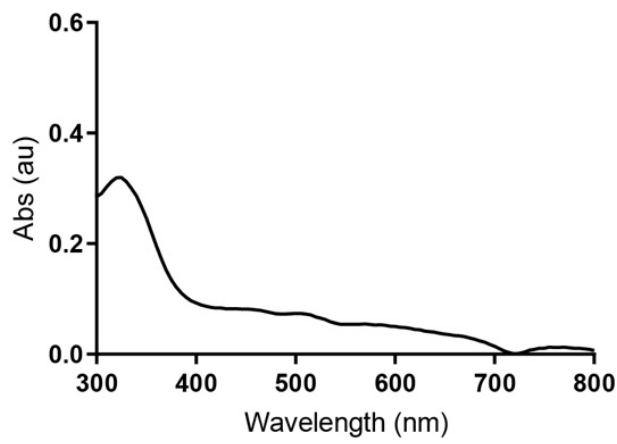

Figure S6. Full scan optical absorbance spectra of fimsbactin analogs 1-Fe, 2-Fe, and 3-Fe ferric iron complexes at $100 \mu \mathrm{M}$ in $\mathrm{pH} 8.0$ aqueous phosphate buffer $(50 \mathrm{mM}$ potassium phosphate, $150 \mathrm{mM} \mathrm{NaCl}, 1 \mathrm{mM}$ DTT, 5\% glycerol). 


\section{Compound Characterization}

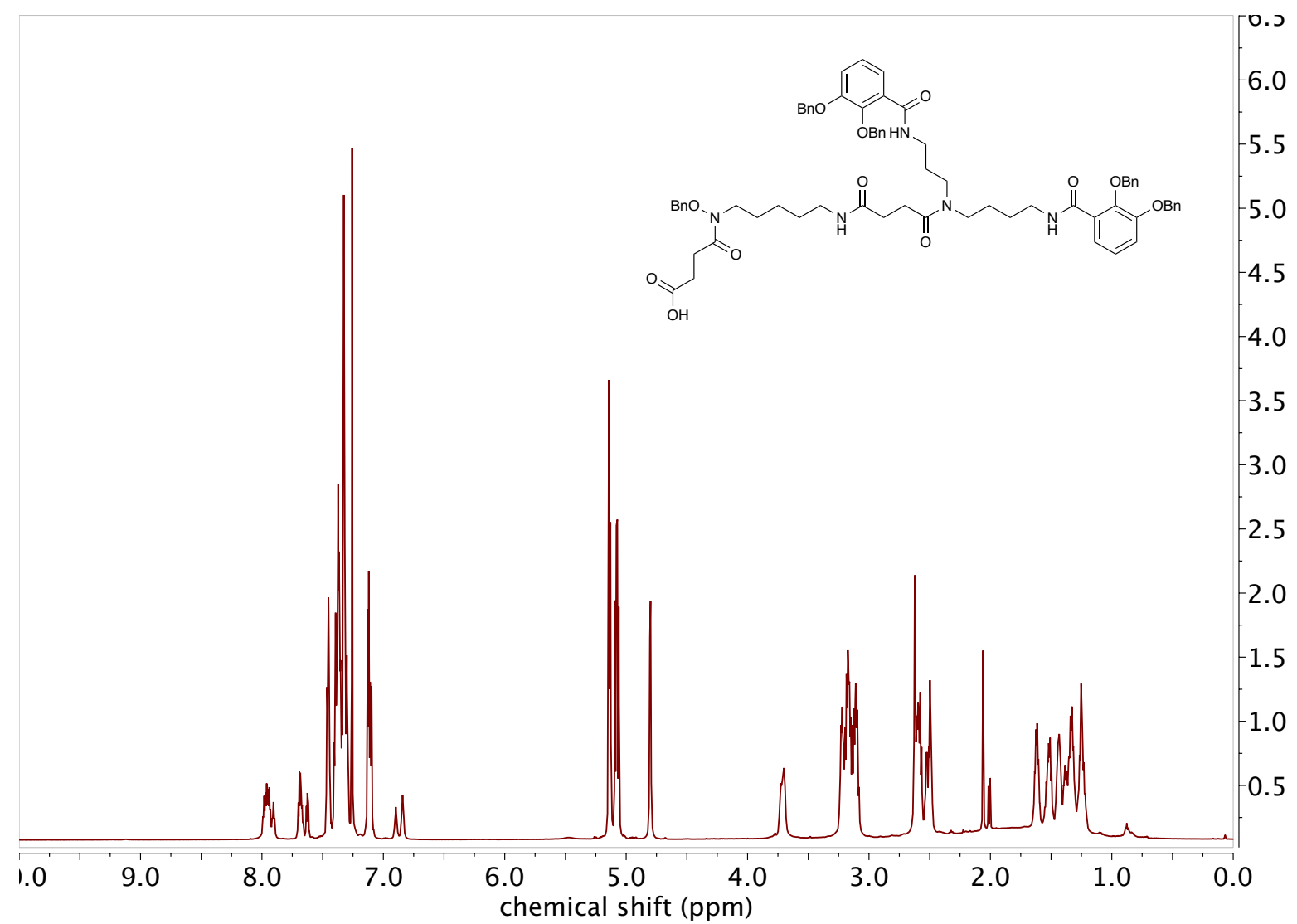

Figure S7. ${ }^{1} \mathrm{H}-\mathrm{NMR}\left(600 \mathrm{MHz}, \mathrm{CDCl}_{3}\right)$ spectrum of compound 14. ${ }^{1,2}$ 


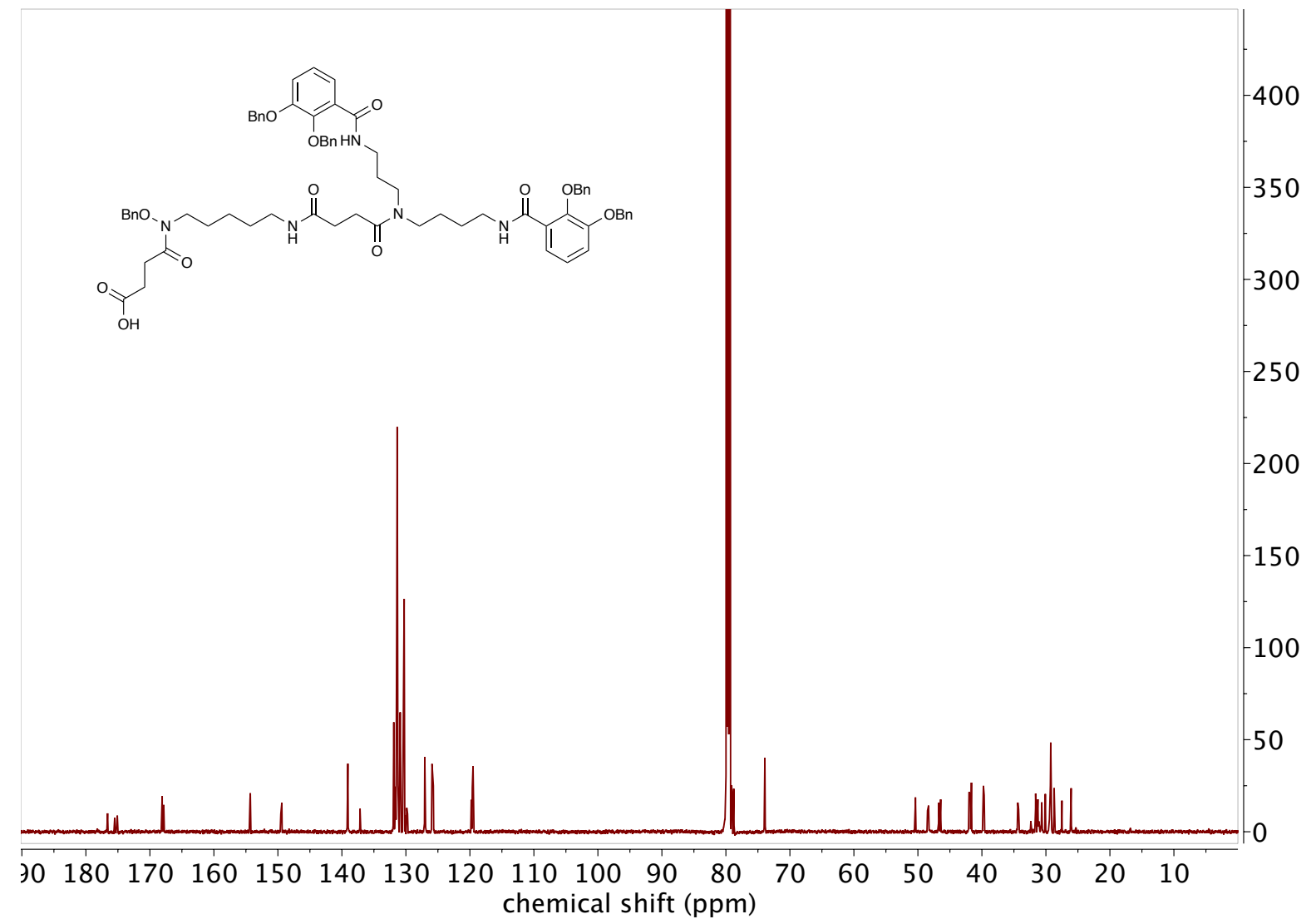

Figure S8. ${ }^{13} \mathrm{C}-\mathrm{NMR}\left(151 \mathrm{MHz}, \mathrm{CDCl}_{3}\right)$ spectrum of compound $\mathbf{1 4 .} .^{1,2}$ 


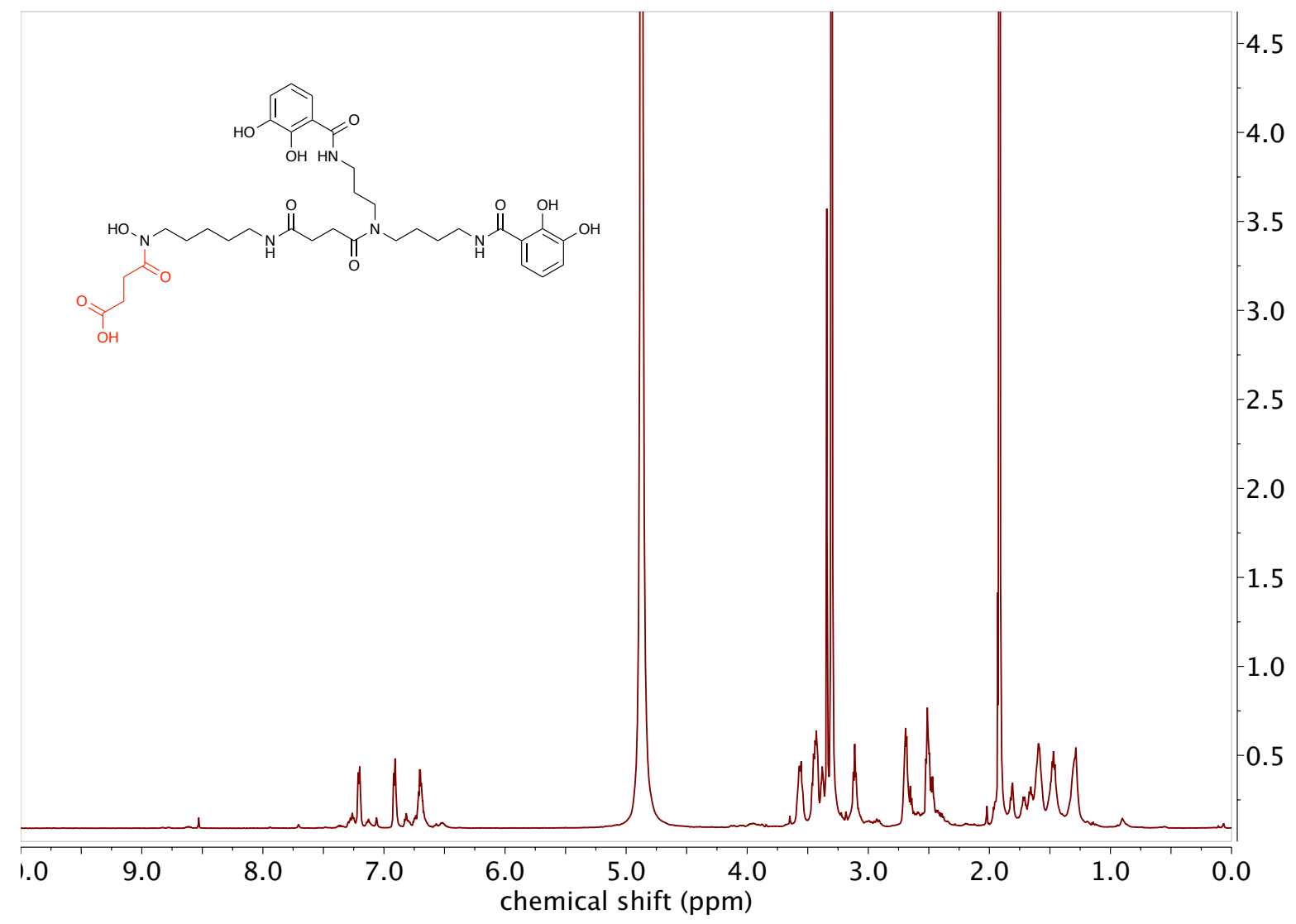

Figure S9. ${ }^{1} \mathrm{H}-\mathrm{NMR}\left(600 \mathrm{MHz}, \mathrm{CD}_{3} \mathrm{OD}\right)$ spectrum of siderophore analog 1. ${ }^{1,2}$ 


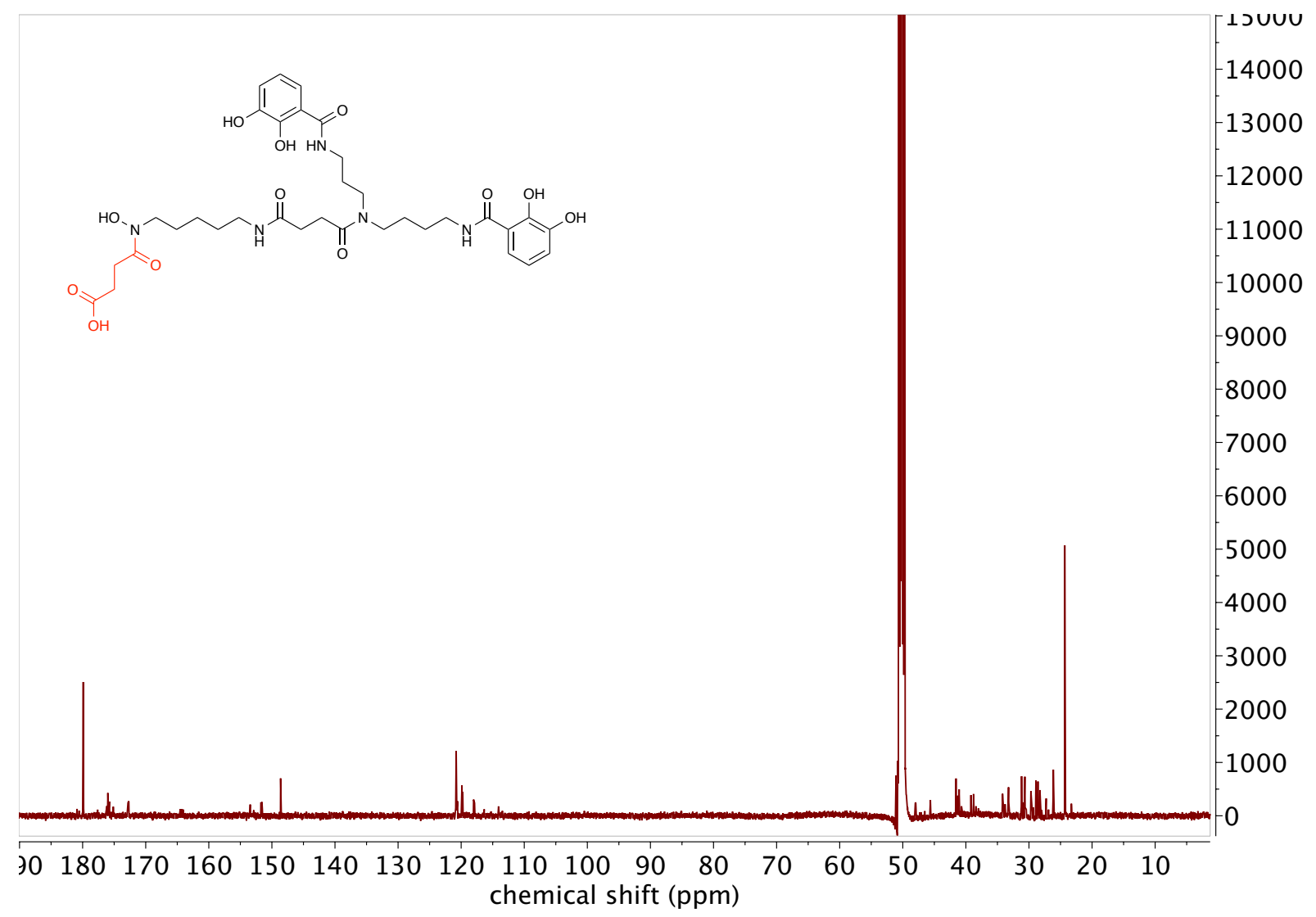

Figure S10. ${ }^{13} \mathrm{C}-\mathrm{NMR}\left(151 \mathrm{MHz}, \mathrm{CD}_{3} \mathrm{OD}\right)$ spectrum of siderophore analog $\mathbf{1 . 1 , 2}$ 


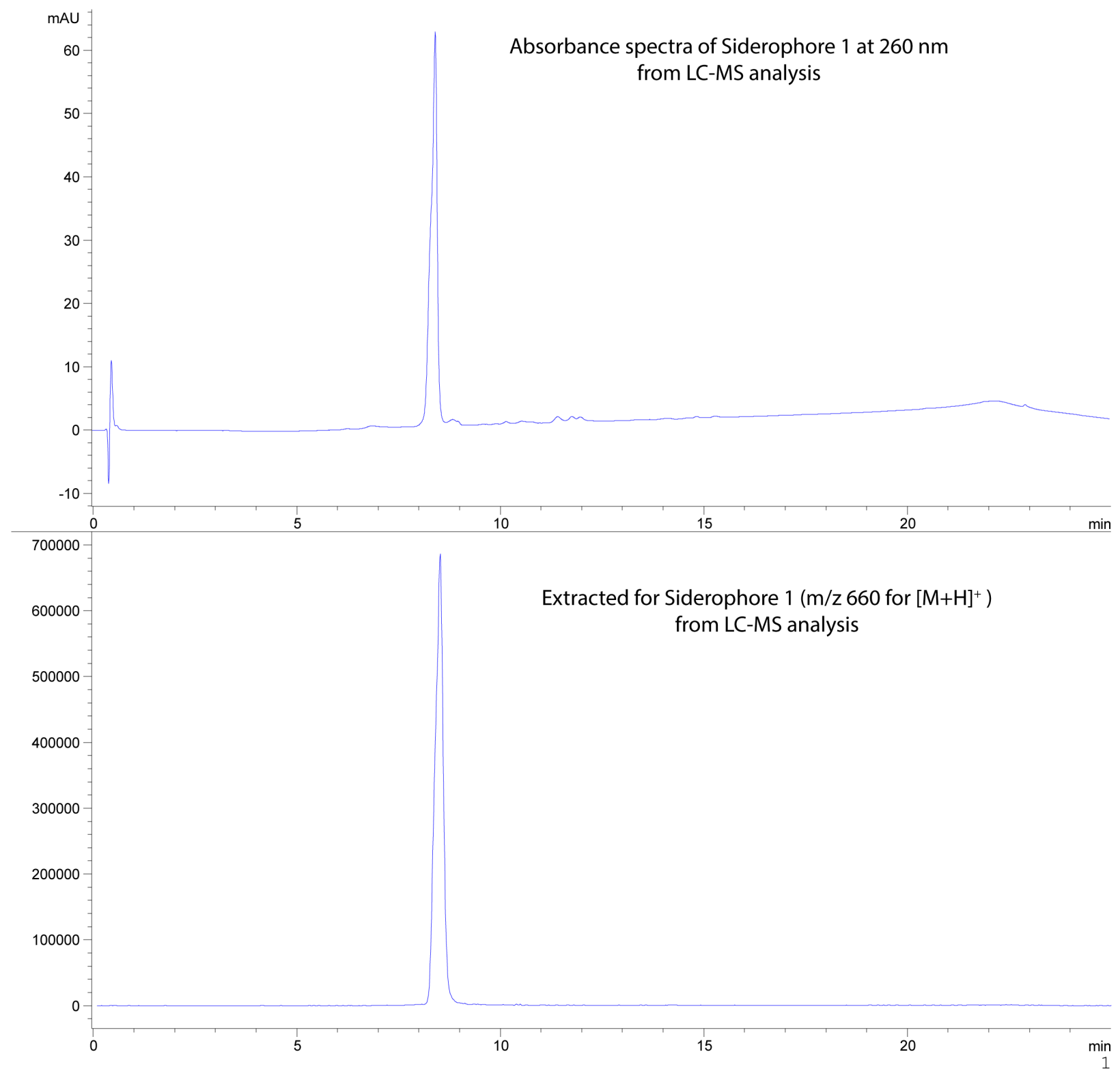

Figure S11. Purity analysis of siderophore 1 by LC-MS (y-axis for bottom panel is extracted ion counts for the $[\mathrm{M}+\mathrm{H}]^{+}$ion). 


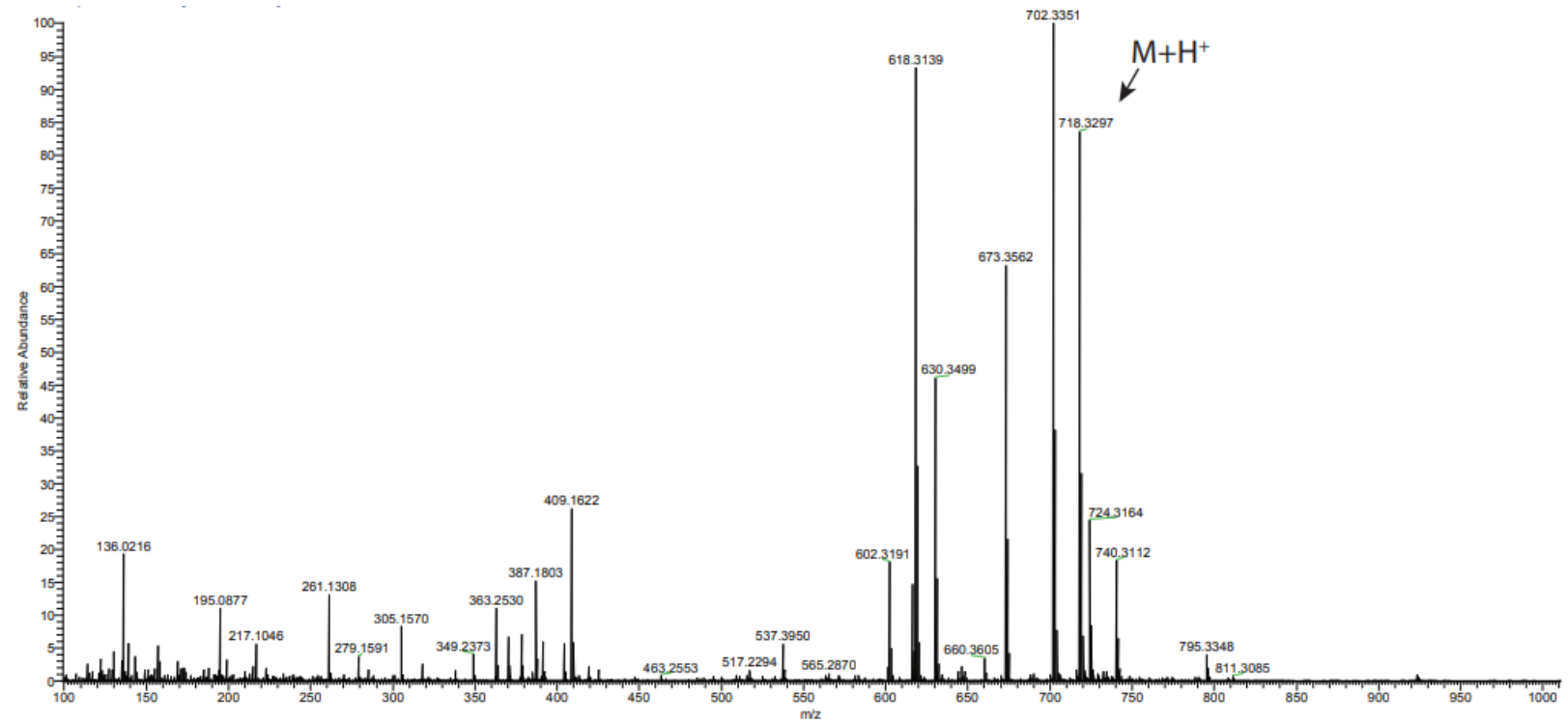

Figure S12. High-resolution ESI MS of siderophore 1 (y-axis shows relative abundance of molecular ions in positive ion mode). 


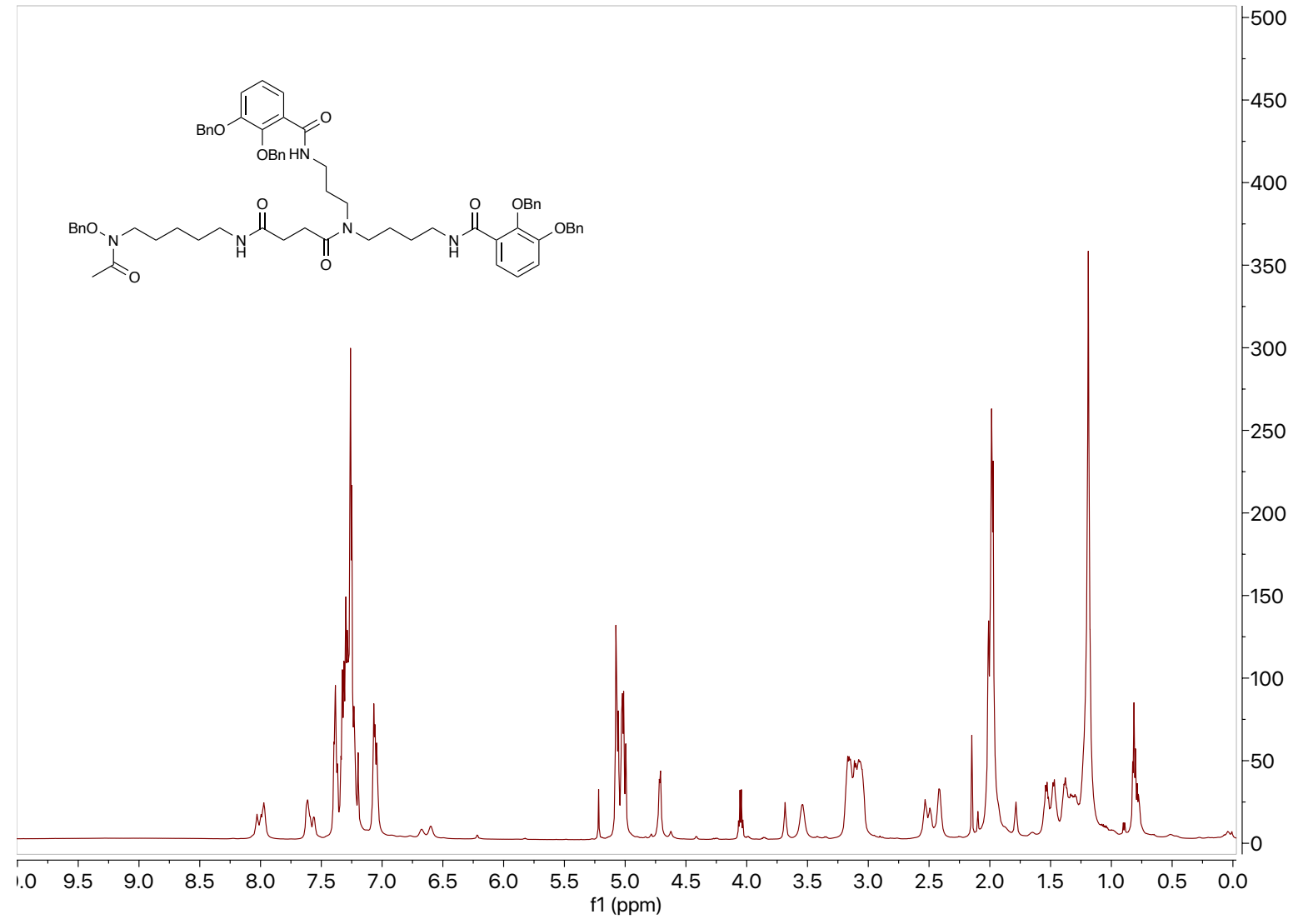

Figure S13. ${ }^{1} \mathrm{H}-\mathrm{NMR}\left(600 \mathrm{MHz}, \mathrm{CDCl}_{3}\right)$ spectrum of compound 15. 


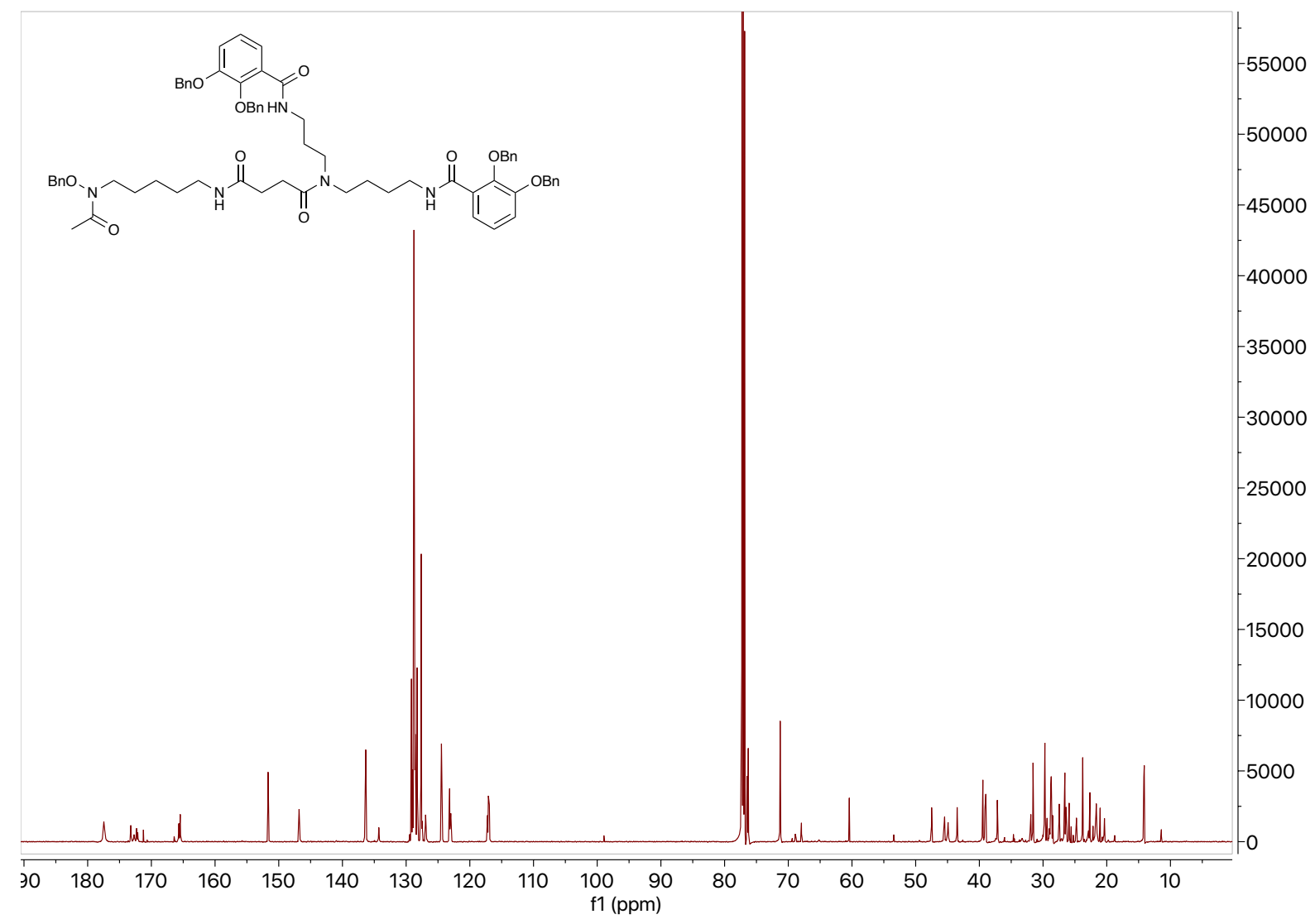

Figure S14. ${ }^{13} \mathrm{C}-\mathrm{NMR}\left(151 \mathrm{MHz}, \mathrm{CDCl}_{3}\right)$ spectrum of compound 15. 


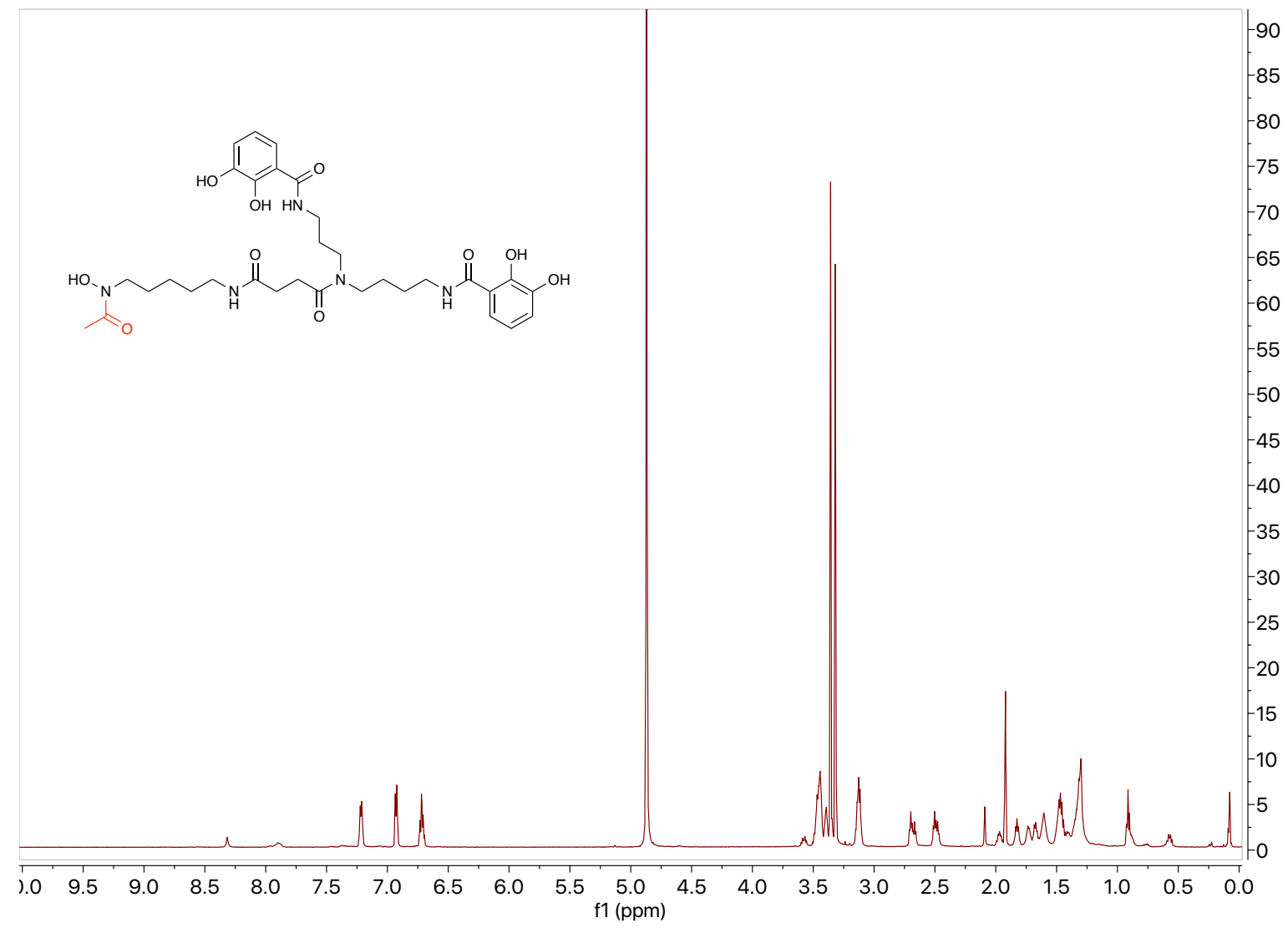

Figure S15. ${ }^{1} \mathrm{H}-\mathrm{NMR}\left(600 \mathrm{MHz}, \mathrm{CD}_{3} \mathrm{OD}\right)$ spectrum of siderophore 2. 


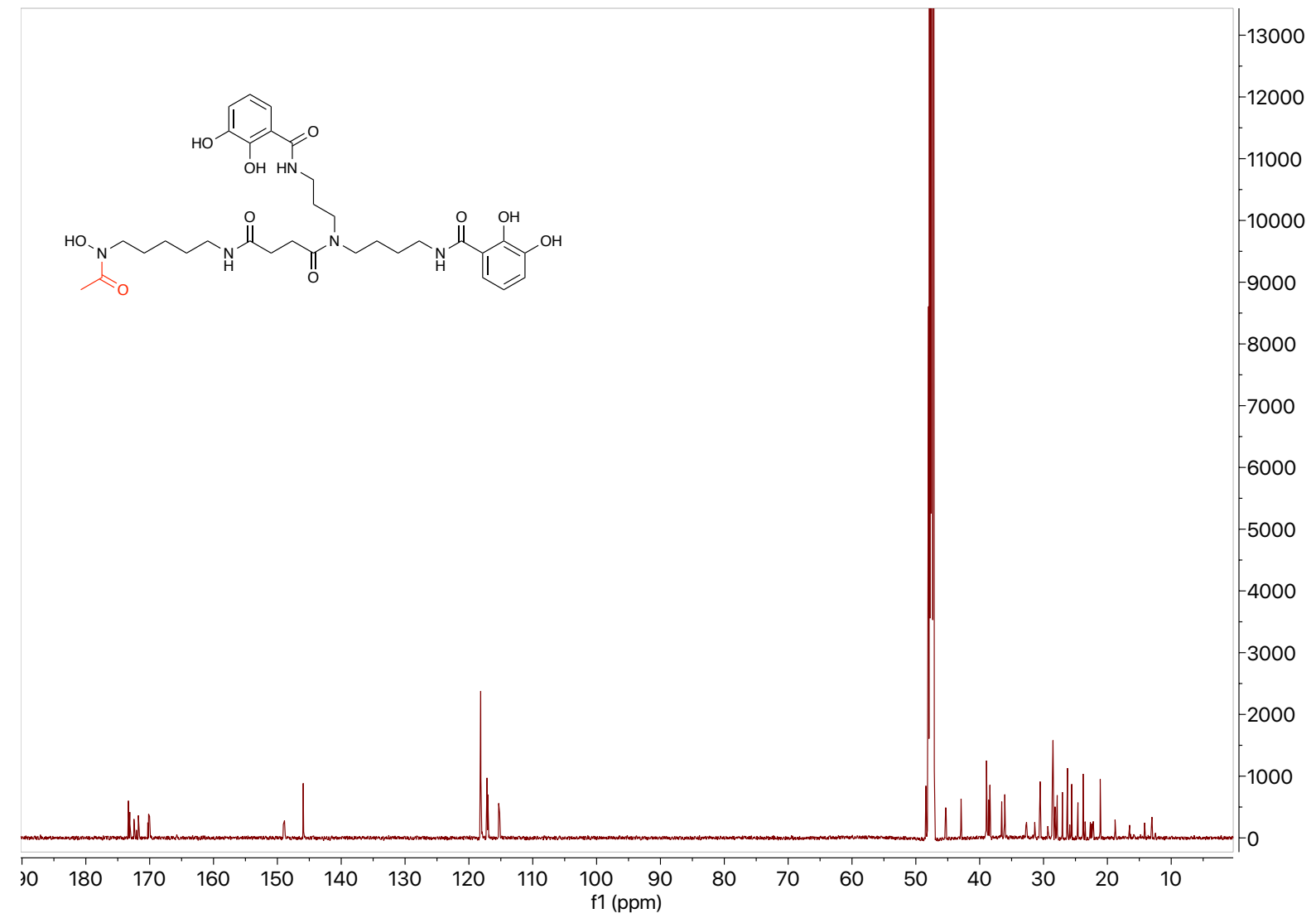

Figure S16. ${ }^{13} \mathrm{C}-\mathrm{NMR}\left(151 \mathrm{MHz}, \mathrm{CD}_{3} \mathrm{OD}\right)$ spectrum of siderophore 2. 


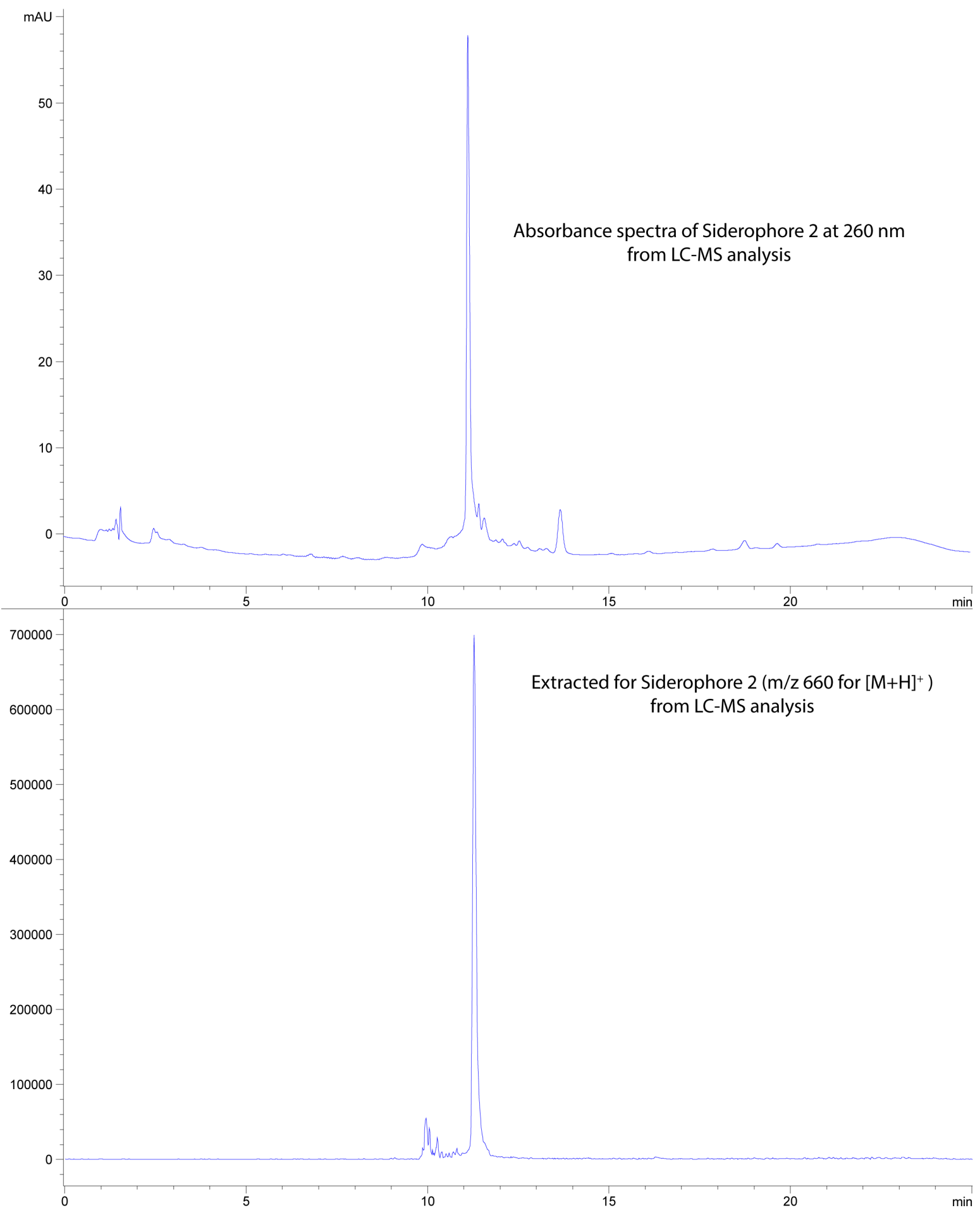

Figure S17. Purity analysis of siderophore 2 by LC-MS (y-axis for bottom panel is extracted ion counts for the $[\mathrm{M}+\mathrm{H}]^{+}$ion). 


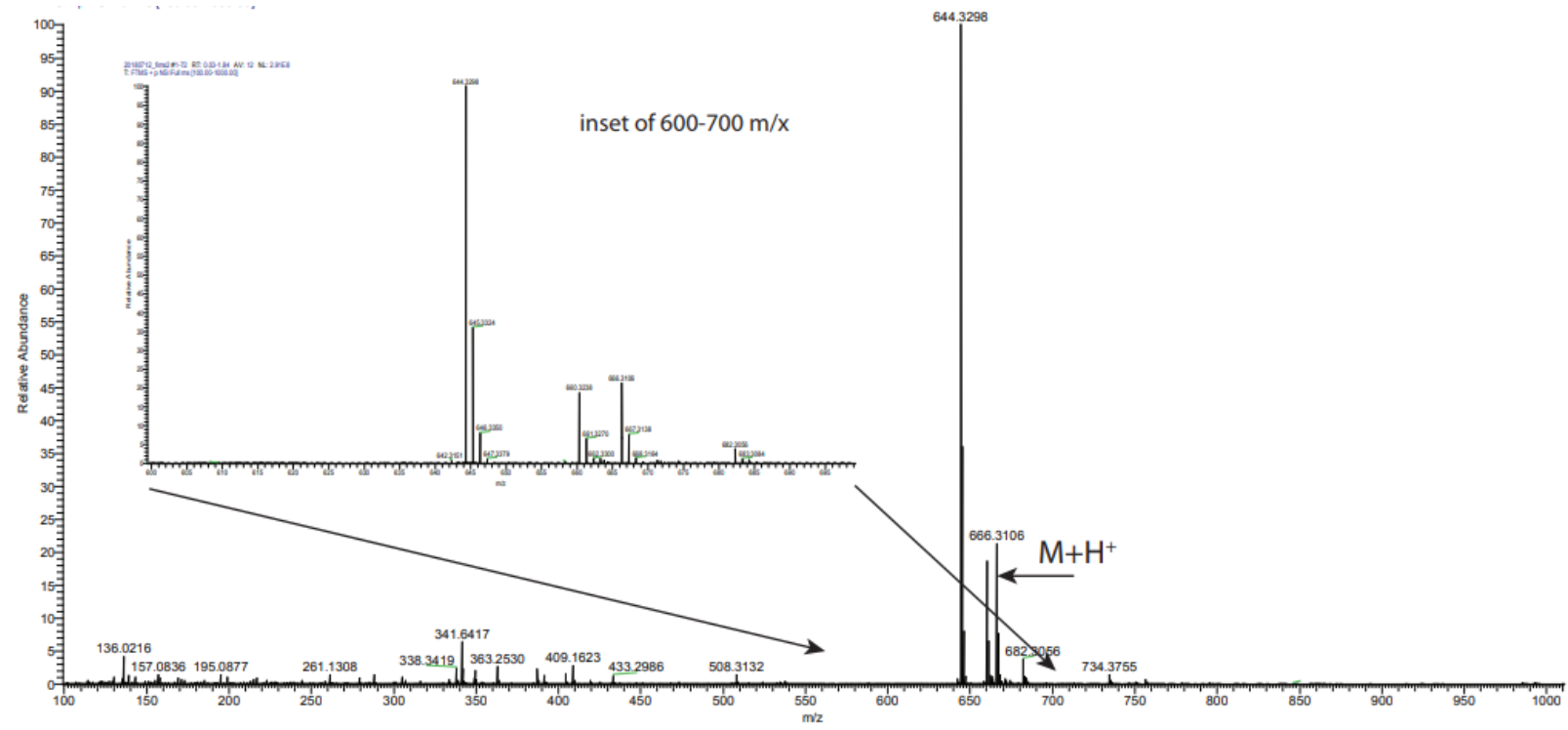

Figure S18. High-resolution ESI MS of siderophore 2 (y-axis shows relative abundance of molecular ions in positive ion mode). 


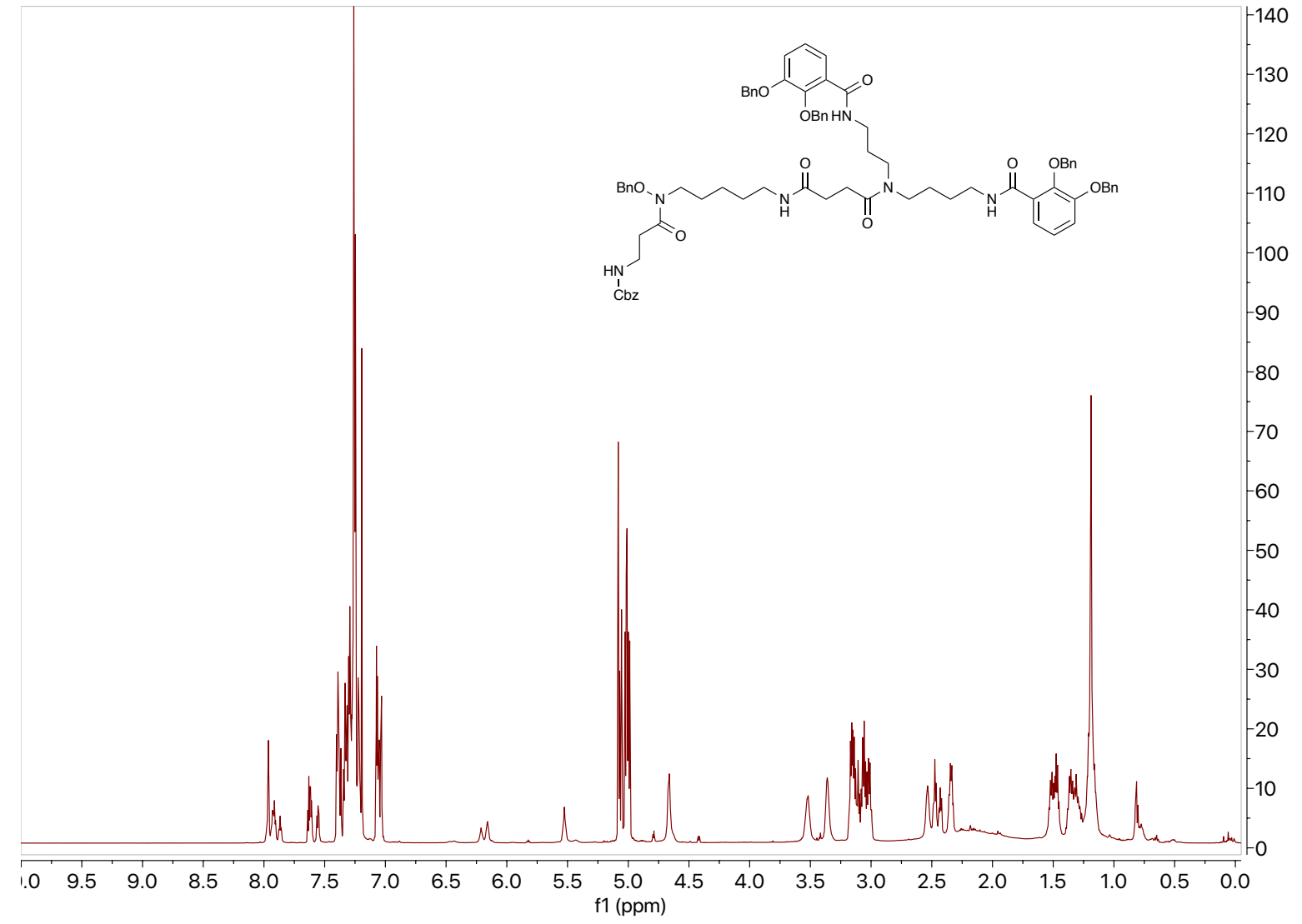

Figure S19. ${ }^{1} \mathrm{H}-\mathrm{NMR}\left(600 \mathrm{MHz}, \mathrm{CDCl}_{3}\right)$ spectrum of compound 16. 


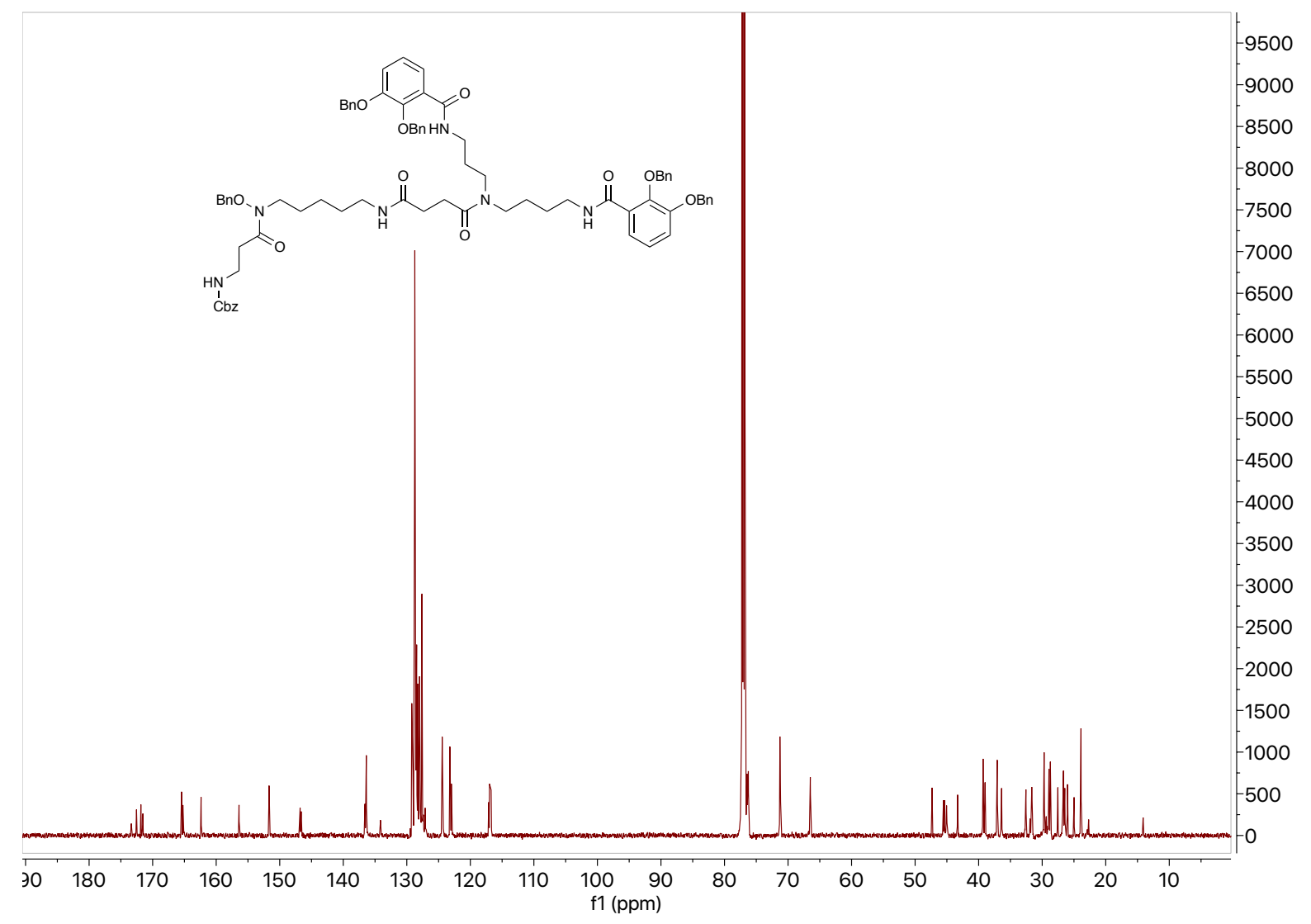

Figure S20. ${ }^{13} \mathrm{C}-\mathrm{NMR}\left(151 \mathrm{MHz}, \mathrm{CDCl}_{3}\right)$ spectrum of compound 16. 


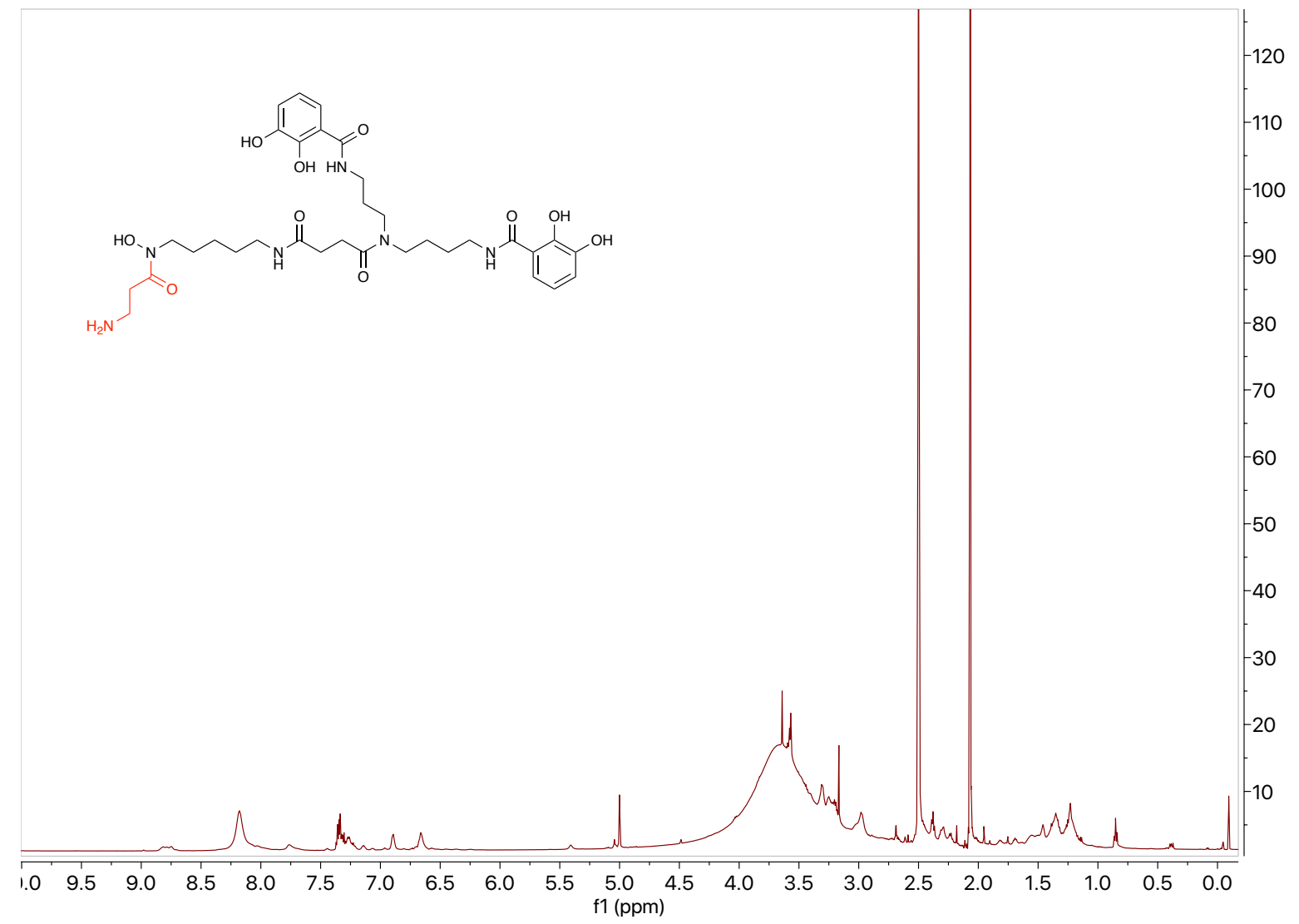

Figure S21. ${ }^{1} \mathrm{H}-\mathrm{NMR}\left(600 \mathrm{MHz}, \mathrm{DMSO}-\mathrm{d}_{6}\right.$ ) spectrum of siderophore 3. 


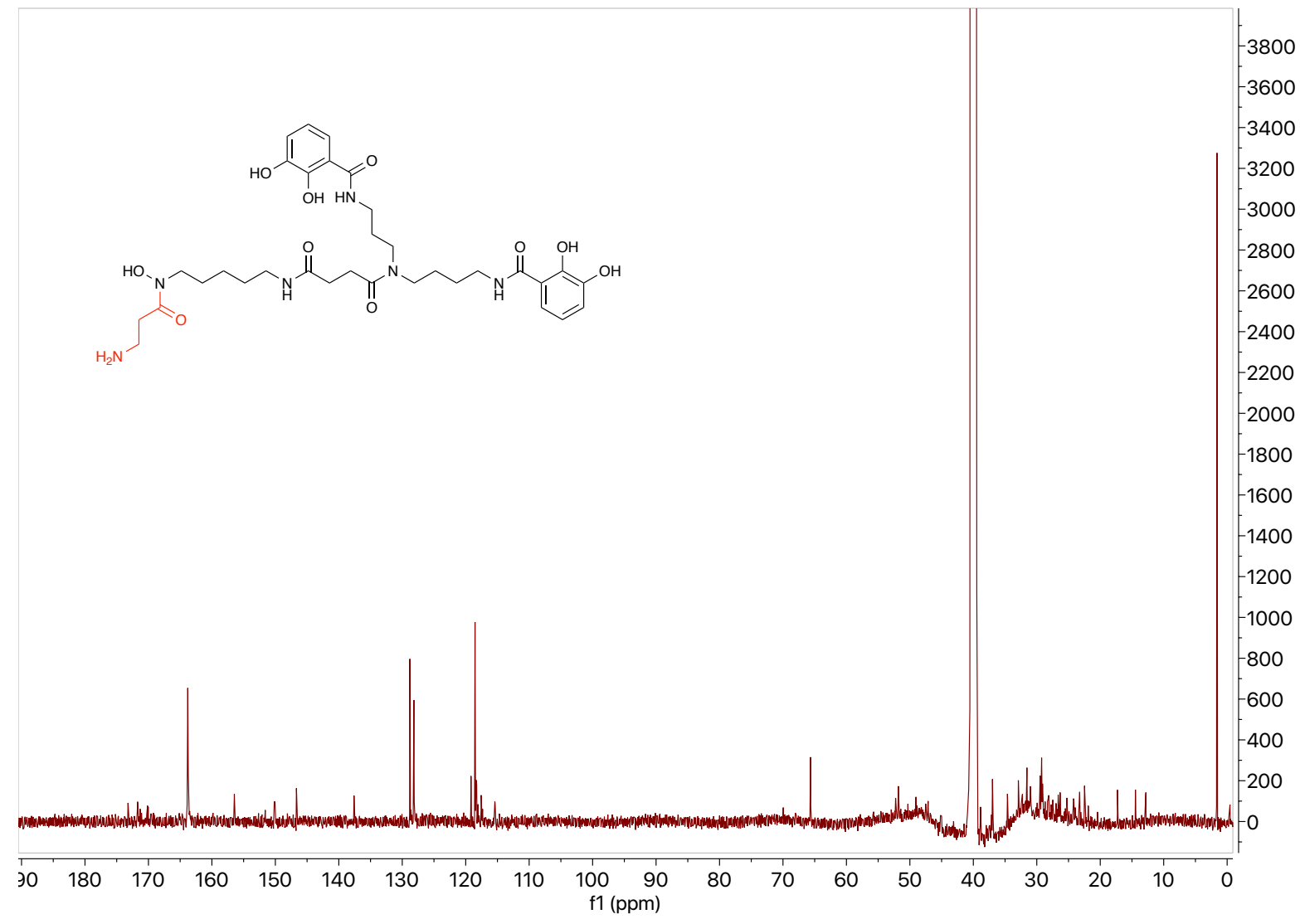

Figure S22. ${ }^{13} \mathrm{C}-\mathrm{NMR}\left(151 \mathrm{MHz}\right.$, DMSO-d $\left.\mathrm{d}_{6}\right)$ spectrum of siderophore 3. 


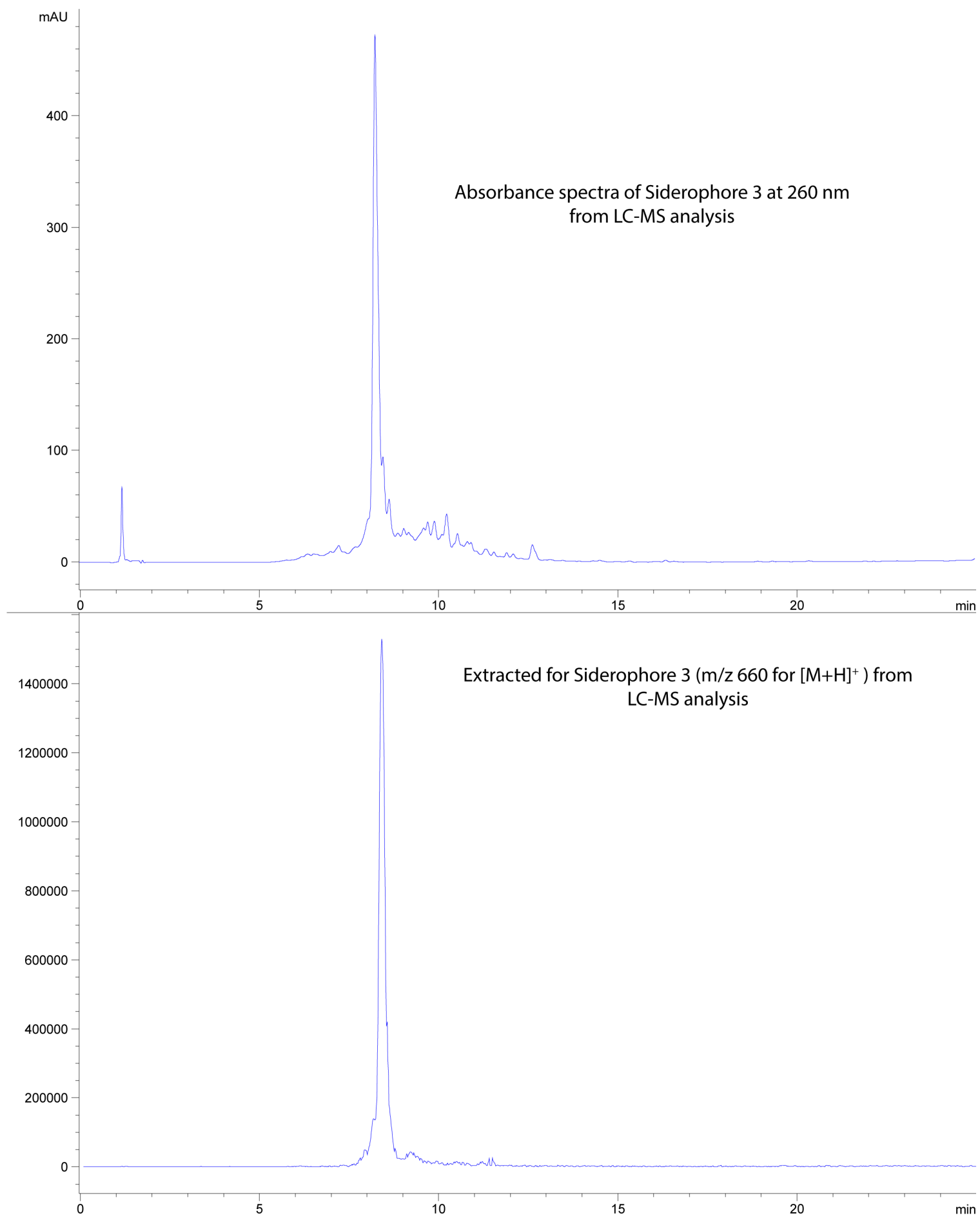

Figure S23. Purity analysis of siderophore 3 by LC-MS (y-axis for bottom panel is extracted ion counts for the $[\mathrm{M}+\mathrm{H}]^{+}$ion). 


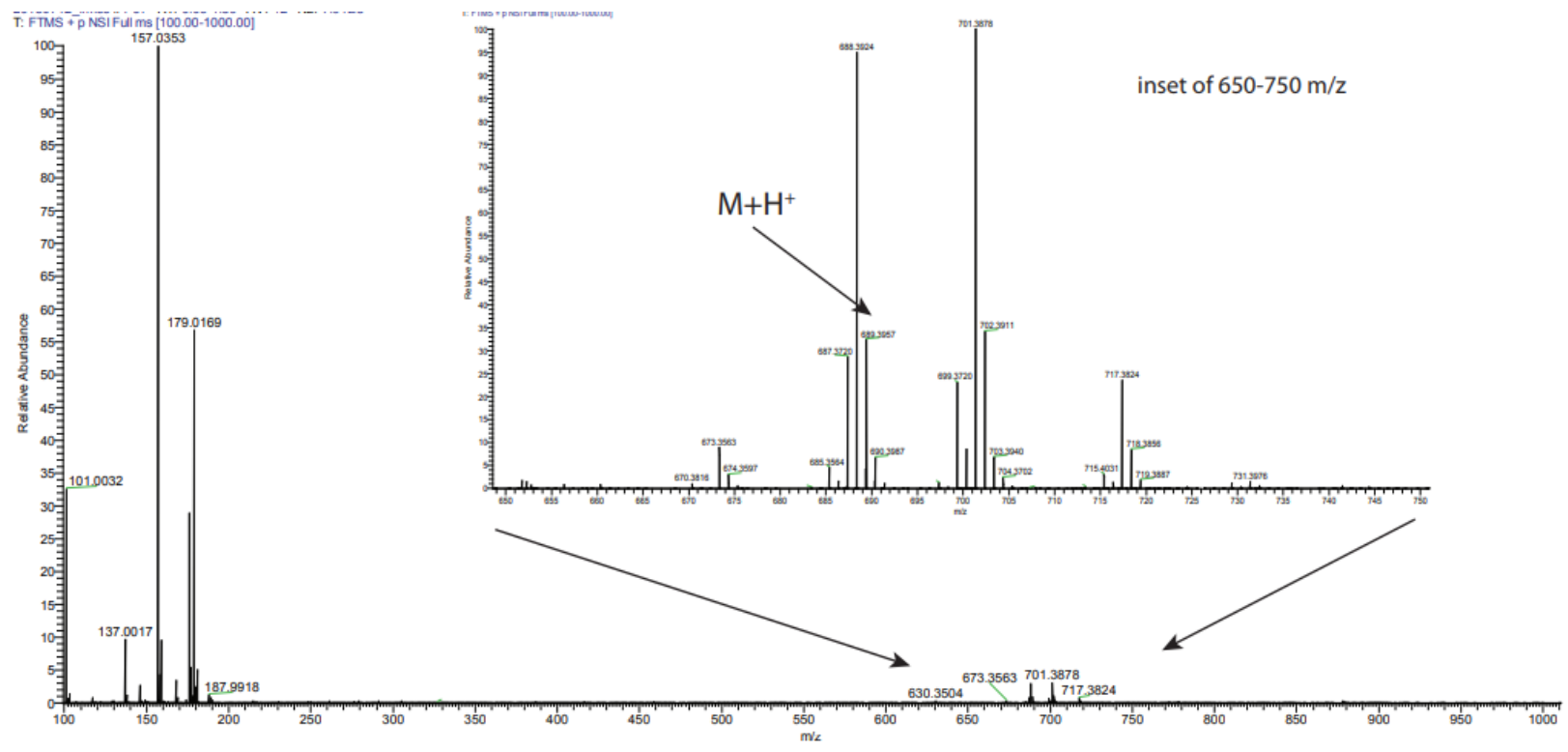

Figure S24. High-resolution ESI MS of siderophore 3 (y-axis shows relative abundance of molecular ions in positive ion mode). 


\section{Acknowledgements}

The authors would like to thank Drs. Jeff Kao and Manmilan Singh (WUSTL Chemistry) for help with the acquisition of 2D NMR data. We also thank Dr. Bradley Evans (Danforth Plant Science Center, St. Louis, MO) for help with the acquisition of HRMS data (NSF DBI-0521250). We thank Dr. Andrew Gulick for supplying the BauB pET28-TEV plasmid construct. ${ }^{3}$ Research in the Wencewicz Lab was supported directly by NSF CAREER Award 1654611 to TAW.

\section{References}

1. Wencewicz, T. A.; Miller, M. J. "Biscatecholate-monohydroxamate mixed ligand siderophore-carbacephalosporin conjugates are selective sideromycin antibiotics that target Acinetobacter baumannii." J. Med. Chem. 2013, 56, 4044-4052.

2. Ghosh, M.; Miller, M. J. Synthesis and in Vitro Antibacterial Activity of Spermidine-Based Mixed Catechol- and Hydroxamate-Containing Siderophore-Vancomycin Conjugates. Bioorganic \& Medicinal Chemistry 1996, 4, 43-48.

3. Bailey, D. C.; Bohac, T. J.; Shapiro, J. A.; Giblin, D. E.; Wencewicz, T. A.; Gulick, A. M. “Crystal structure of the siderophore binding protein BauB bound to an unusual 2:1 complex between acinetobactin and ferric iron." Biochemistry 2018, 57 (48), 6653-6661. 